\title{
Correction to: Extracellular Vesicles: Biomarkers, Therapeutics, and Vehicles in the Visual System
}

\author{
Yolandi van der Merwe $\mathrm{M}^{1,2,3} \cdot$ Michael B. Steketee ${ }^{2,3,4}$
}

Published online: 23 January 2018

(C) The Author(s) 2018. This article is an open access publication

\section{Correction to: Curr Ophthalmol Rep (2017) 5:276-282 https://doi.org/10.1007/s40135-017-0153-0}

The article Extracellular Vesicles: Biomarkers, Therapeutics, and Vehicles in the Visual System, written by Yolandi van der Merwe and Michael B. Steketee, was originally published Online First without open access. After publication in volume [5], issue [4], page [276-282] the author decided to opt for Open Choice and to make the article an open access publication. Therefore, the copyright of the article has been changed to (C) The Author(s) 2018 and the article is forthwith distributed under the terms of the Creative Commons Attribution 4.0 International
License (http://creativecommons.org/licenses/by/4.0/), which permits use, duplication, adaptation, distribution and reproduction in any medium or format, as long as you give appropriate credit to the original author(s) and the source, provide a link to the Creative Commons license, and indicate if changes were made.

Open Access This article is distributed under the terms of the Creative Commons Attribution 4.0 International License (http:// creativecommons.org/licenses/by/4.0/), which permits unrestricted use, distribution, and reproduction in any medium, provided you give appropriate credit to the original author(s) and the source, provide a link to the Creative Commons license, and indicate if changes were made.

The online version of the original article can be found at https://doi.org/ 10.1007/s40135-017-0153-0.

Michael B. Steketee

SteketeeM@UPMC.edu

1 Department of Bioengineering, University of Pittsburgh, Pittsburgh, PA 15260, USA

2 Department of Ophthalmology, University of Pittsburgh, Pittsburgh, PA 15216, USA

3 McGowan Institute for Regenerative Medicine, University of Pittsburgh, 450 Technology Drive, Suite 300, Pittsburgh, PA 15219, USA

4 Center for Neuroscience, University of Pittsburgh, Pittsburgh, PA 15261, USA 